Agro-Science Journal of Tropical Agriculture, Food, Environment and Extension Volume 20 Number 4 (Special Issue, October 2021) pp. 1 - 7

ISSN 1119-7455

\title{
YAM PRODUCTION IN SOME SOUTH EAST AND NORTH CENTRAL ZONES OF NIGERIA BEYOND COVID-19 FOR ACCELERATION TOWARDS INCLUSIVE SUSTAINABLE DEVELOPMENT
}

\author{
${ }^{* 1,2}$ Ufondu H.E., ${ }^{1}$ Maziya-Dixon B. and ${ }^{2}$ Okonkwo T.M. \\ ${ }^{1}$ Food Science \& Nutrition Laboratory, International Institute of Tropical Agriculture, Ibadan, Nigeria \\ ${ }^{2}$ Department of Food Science \& Technology, University of Nigeria, Nsukka, Nigeria \\ *Corresponding author's email: helenufondu@gmail.com
}

\begin{abstract}
This study evaluated the effect of socio-economic characteristics of small-scale yam farmers on the productivity and income levels of yam farmers beyond COVID-19 in some part of yam producing areas of South East and North Central zones (Benue, Ebonyi, Enugu and Kogi States) of Nigeria. Respondents (200) were selected by random sampling using a structured questionnaire. Data were analyzed using descriptive and correlation analysis. Majority of the respondents (71.7\%) were male. COVID-19 will have serious negative impacts on the productivity and income of the yam farmers due to sex difference in angiotensin converting enzyme (ACE) 2 receptor and transmembrane serine protease 2 TMPRSS2 regulations. Majority (34.8\%) of the respondents were within the age range of 55-64 years which might place them at increased risk of severe impact from COVID-19. Most of the respondents (37.9\%) were with First School Leaving Certificate (FSLC) which will be aggravated by global lockdown of education institutions. COVID-19 pandemic has created the largest disruption of education systems due to closure of schools and other learning spaces as well as inability of many parents to work making financing of education to face big challenges. Most of the respondents (35.4\%) had farm size of three hectares. Most of the respondents (37.9\%) earned between $\$ 151,000$ and $\$ 200,000$ per hectare. This income informal economy will be affected by COVID-19 control measures. Majority of the respondents (70.2\%) had between 21 to 30 years of yam farming experience. At this length of experience, it is expected that they will be within the age range that is more vulnerable to COVID-19 pandemic. Using Pearson correlation coefficient to assess the relationship between socio-economic factors farm characteristics of small-scale yam farmers establishes that farm experience significantly $(p<0.05)$ correlated with age of the respondents. Marital status was significantly $(p<0.05)$ correlated with age $(0.548)$ and farm experience $(0.932)$ of the respondents.
\end{abstract}

Key words: yam farmers, socio-economic factors, productivity, small-scale

\section{INTRODUCTION}

Agriculture is the sector where the poor can most easily benefit from inclusive sustainable growth, which is essential for sustainable development via increased productivity. In many African countries, substantial efforts are needed to sustain and accelerate agricultural development for improving productivity beyond COVID-19. Small-scale farming has been pinpointed to be a crucial avenue for inclusive economic development for rural communities (Mubamba et al., 2018). While there is a consensus that smallholder producers play important role in the production system, they face many socio-economic and cultural constraints (Dagbelou et al., 2021). The General Household Survey (GHS) conducted by Statistics South Africa in 2014 revealed that the number of small-scale famers in rural areas had decreased by $19.1 \%$ from 2,880,000 in 2011 to 2,330,000 in 2016 (Muzekenyi et al., 2019). The majority of African populations, including Nigeria depend on subsistence and small- scale agriculture to attain food security and generate incomes. Therefore, this reduction may suggest the migration to other professions with consequent low agricultural production by the remainder and resultant food insecurity. According to Ajibola (2020), 70\% of African's population, Nigeria in particular live in rural areas and are responsible for about 75 percent of Nigerian's food production. Majority of the rural populace are predominantly smallholder farmers who produce staple food crops such as rice, yam, cowpea, cassava, maize, sorghum, millet and vegetables (Ajibola, 2020). Yam is a high-value crop in West Africa. Nigeria is the world's largest yam producer (Bergh et al., 2012). In Nigeria, yam has a higher production value than all the other five major food staples; maize, cassava, rice, millet and sorghum combined (IITA, 2020).

Yam is an annual crop and the critical starting point of the growing season is when dormancy ends, sprouts are produced, Yam tubers when stored beyond their planting season sprouts profusely. One

Please cite as: Ufondu H.E., Maziya-Dixon B. and Okonkwo T.M. (2021). Yam production in some South East and North Central zones of Nigeria beyond COVID-19 for acceleration towards inclusive sustainable development. Agro-Science, 20 (4, Special Issue), 1-7. DOI: https://dx.doi.org/10.4314/as.v20i4.1 
can extend the planting time by cutting off the shoots; and this can only be done twice at a month interval (IITA, 2020). Sprouting causes loss of nutrients and loss of water, resulting in tuber becoming more fibrous and lighter in weight, If the seed tubers remain in storage for more than two months after sprouting without planting, the farmer loses up to three-quarters of their potential yield capacity and production volume. Yam producers and traders report diverse constraints to their full participation in the market, including high cost of inputs, planting materials and labor, lack of credit, limited access to proper storage facilities, and high transportation costs. Despite national root crops research institutes and other higher institutions in Nigeria, agricultural productivity and improved livelihood remained low partly as a result of lack of appropriate technologies or lack of access to those technologies, inputs, credit and access to markets and rural infrastructure. Other constraints include gaps in information and skills that prevent rural producers from effectively utilizing and adopting technologies (Mapila et al., 2011).

The situation has been compounded by COVID19 outbreak, which was reported shortly before the rainy season (March-April in the study area) that marked the beginning of planting season. COVID19 affects males more than females. To enter cells, SARS-Cov-2 (severe acute respiratory syndrome coronavirus 2), binds to the angiotensin converting enzyme (ACE2) receptor and the cellular serine protease (TMPRSS2) for priming (Hoffmann et al., 2020). Some reports indicated that circulating levels of ACE2 are higher in men compared to women (Patel et al., 2013). There is enough evidence that sex and sex hormones affect many components of the circulating as well as tissue-based ACE2 (Chappell et al., 2014). Thus, testosterone (men) seems to maintain high ACE2 levels in the heart and kidney, whereas estrogen (women) reduces ACE2 expression in these organs. Klein et al. (2010) reported that females generally exhibit greater humoral and cell-mediated immune responses to antigenic stimulation, vaccination, and infection than do males. Gender-related risk factors might also have impact on the higher risk of more susceptibility of males to COVID-19 than females. Cai (2020) reported that gender differences in risk behaviors, such as smoking and drinking which are higher in men than women worldwide may be contributing to a higher incidence among men. Other gender norms and behaviours which may be contributing to a higher incidence among men include lower rates of hand washing, which is a recognized preventative measure, and delayed healthcare seeking (Ahmed and Dumanski, 2020).

COVID-19 containment measures such as physical distancing and stay at home order among other things had brought physical limitations to farm production and access to labour. Staying at home (because most farmers and labourers travel/move some distances from home) order will incur too much losses to yam farmers will incur too much losses on yam farmers which will lead to reduction in yield thus aggravating the problem of food insecurity especially among rural farmers. While COVID-19 was causing food insecurity and economic depression in general, it was also an opportunity for Nigeria to explore, among other things a greater emphasis on policies and strategies that will help the country to recover and come out stronger from COVID-19 pandemic, improve their contributions to local communities and strengthen farming activities. In order to combat the risk of food insecurity and poverty, national strategic measures should be taken towards protecting the most vulnerable rural dwellers, thus promoting long-term productivity during COVID-19 period and after. This paper, therefore, assesses the impact of socioeconomic factor of rural small-scale yam farmers on the productivity and income in some yam producing, processing and consuming areas of South East and North central zone of Nigeria.

\section{METHODOLOGY}

\section{Study Area}

The study adopted cross sectional survey, carried out in Benue, Ebonyi, Enugu and Kogi States of Nigeria. In Benue State, Logo (1,408 km², 170,000 inhabitants, latitudes $6^{\circ} 25^{\prime} \mathrm{N}$ and $8^{\circ} 8^{\prime} \mathrm{N}$, longitudes $7^{\circ} 47^{\prime} \mathrm{E}$ and $\left.10^{\circ} 0^{\prime} \mathrm{E}\right)$, Katsina-Ala $\left(2,402 \mathrm{~km}^{2}\right.$, population of 224,718 at the 2006 census [being the latest census figure operational and in use in Nigeria], $7^{\circ} 10^{\prime} 0^{\prime \prime} \mathrm{N}, 9^{\circ} 17^{\prime} 0$ " E) local government areas were selected. In Ebonyi State, Afikpo $\left(240 \mathrm{~km}^{2}\right.$, population of 156,611 at the 2006 census) and Izzi (population 250,459, 6 $34^{\prime} 60^{\prime \prime} \mathrm{N}$ and $8^{\circ} 3^{\prime} 0^{\prime \prime} \mathrm{E}$ ) were selected. In Enugu State, Igbo-Eze $\left(158 \mathrm{~km}^{2}\right.$, a population of 147,328 at the 2006 census, $\left.6^{\circ} 55^{\prime} \mathrm{N}^{\circ} 24^{\prime} \mathrm{E}\right)$ and Nsukka $\left(1,810 \mathrm{~km}^{2}\right.$ and a population of 309,633 at the 2006 census, $\left.6^{\circ} 51^{\prime} \mathrm{N}^{\circ} 23^{\prime} \mathrm{E}\right)$ were selected. In Kogi State, Dekinna $\left(2,461 \mathrm{~km}^{2}\right.$, population of 260,312 at the 2006 census $\left.7^{\circ} 41^{\prime} 41^{\prime \prime} \mathrm{N} 7^{\circ} 01^{\prime} 20^{\prime \prime} \mathrm{E}\right)$ and Omala $\left(1,667 \mathrm{~km}^{2}\right.$ and a population of 108,402 at the 2006 census, $7^{\circ} 43^{\prime} \mathrm{N}^{\circ} 33^{\prime} \mathrm{E}$ ) (longitude $6^{\circ} 53^{\prime \prime} \mathrm{E}$ ) were selected. The states and local government areas where the survey was carried out are shown in Figure 1.

\section{Sampling Technique}

A multi-stage sampling technique described by Mbanaso et al. (2011) was employed in study area where yams are currently grown intensively and/or is commercially processed and consumed. A sample group comprising 200 respondents was formed in the following manner:

- Purposive selection of 200 respondents from four states in the North Central (Benue and Kogi) South East (Enugu and Ebonyi) geographical zones of Nigeria. 


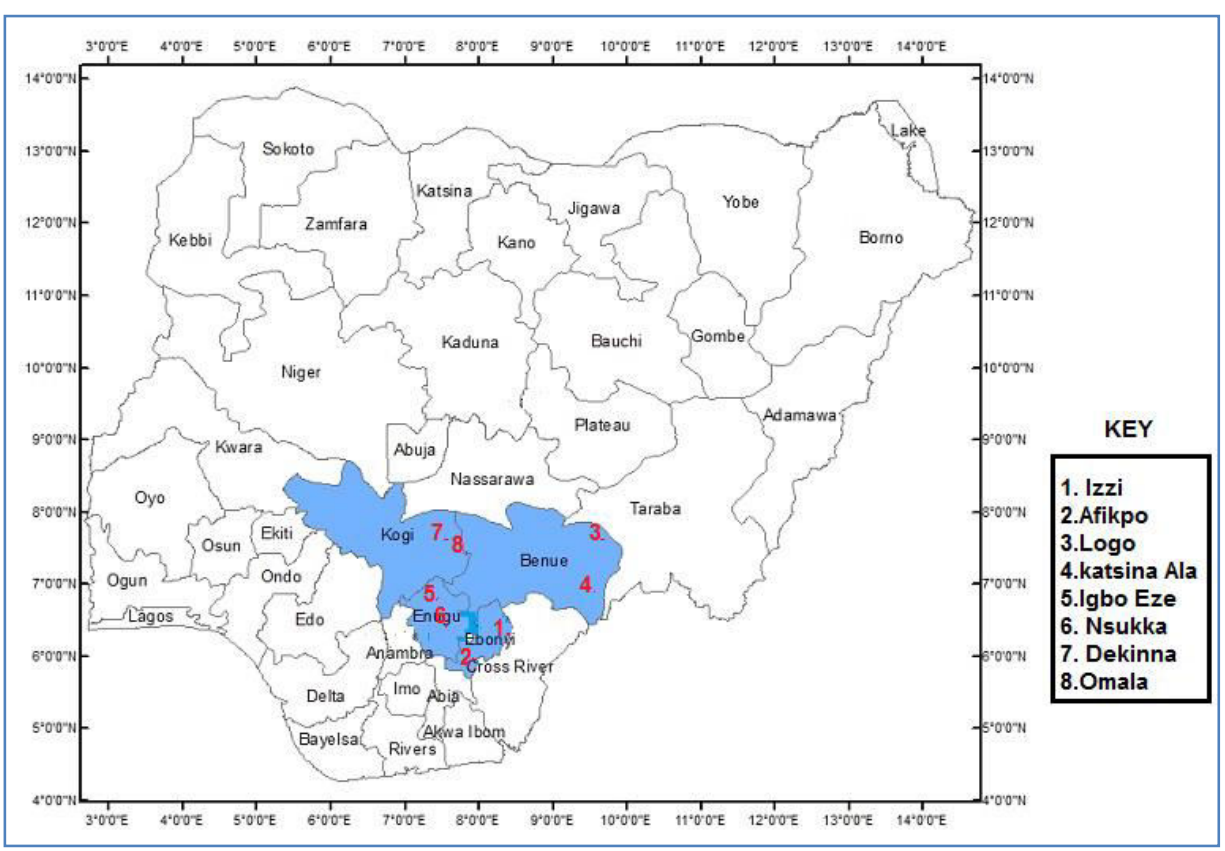

Figure 1: Map of Nigeria showing the sites of yam production and data collection

- Simple random sampling was used to select two local government areas from Ebonyi (Izzi, Afikpo), Benue (Logo, Katsina-Ala), Enugu (Igbo-Eze, Nsukka), Kogi (Dekinna and Omala) with 50 respondents each.

- Twenty-five respondents were randomly selected from two communities within each local government area; Izzi (Oferekpe, Agbaja), Afikpo (Amaizu, Ukpa), Logo (Anyiw, Tse Bamum), Katsina-Ala (AuleGber, Uji-Monkwar), Igbo-Eze (Amankwo, Aguneze), Nsukka (Okpuje, Uzoanyinyaugwu), Dekinna (Anyigba, Odu) and Omala (Olohwu and Ajob).

\section{Data Collection and Analysis}

This study collected data by the use of structured questionnaires, which were administered to yam farmers in the study area. Enumerators used the native language of the people in the process of administering the questionnaire.

Descriptive and correlation analysis of the data collected were carried out using Statistical Analysis Systems (SAS) version 9.4 (SAS, 2012). Potential relationship between socio-economic factors and farm characteristics were determined by the use of Pearson's correlation.

\section{RESULTS AND DISCUSSION}

Socio-Economic Characteristics of Respondents

The distributions of respondents according to their socio-economic characteristics are summarized in Table 1. Majority of the respondents $(71.7 \%)$ were males. This finding implies that male dominates yam farming in the study areas. The high ratio of male to female yam farmers in the study area might be due to the role of women as housewives. It may also be due to the strenuous nature of yam cultivation.
Table 1: Socio-economic characteristics of respondents

\begin{tabular}{|c|c|c|}
\hline $\begin{array}{l}\text { Socio-economic } \\
\text { characteristic }\end{array}$ & $\begin{array}{l}\text { Number of } \\
\text { respondents }\end{array}$ & Percentages \\
\hline \multicolumn{3}{|l|}{ Sex } \\
\hline Male & 143.4 & 71.7 \\
\hline Female & 56.6 & 28.3 \\
\hline \multicolumn{3}{|l|}{ Age (years) } \\
\hline $15-24$ & 0.0 & 0.0 \\
\hline $25-34$ & 5.0 & 2.5 \\
\hline $35-44$ & 36.4 & 18.2 \\
\hline $45-54$ & 59.6 & 29.8 \\
\hline $55-64$ & 99.0 & 49.5 \\
\hline$>65$ & 0.0 & 0.0 \\
\hline \multicolumn{3}{|l|}{ Marital status } \\
\hline Single & 61.6 & 30.8 \\
\hline Married & 138.4 & 69.2 \\
\hline \multicolumn{3}{|l|}{ Educational level } \\
\hline No education & 20.1 & 10.1 \\
\hline FLSC & 105.1 & 52.5 \\
\hline WAEC/GCE & 18.2 & 9.1 \\
\hline $\mathrm{OND} / \mathrm{HND} / \mathrm{BSC}$ & 19.2 & 9.6 \\
\hline \multirow{2}{*}{\multicolumn{3}{|c|}{ Farm area (hectares) }} \\
\hline & & \\
\hline 1.0 & 5.0 & 2.5 \\
\hline 1.5 & 10.0 & 5.0 \\
\hline 2.0 & 10.2 & 5.1 \\
\hline 2.5 & 2.0 & 1.0 \\
\hline 3.0 & 22.2 & 11.1 \\
\hline 4.0 & 130.6 & 65.3 \\
\hline 6.0 & 10.0 & 5.0 \\
\hline 7.0 & 10.0 & 5.0 \\
\hline \multicolumn{3}{|c|}{ Farming experience (years) } \\
\hline $1-10$ & 0.0 & 0.0 \\
\hline $11-20$ & 0.0 & 0 \\
\hline $21-30$ & 6.0 & 3 \\
\hline $31-40$ & 131.4 & 65.7 \\
\hline 41 and above & 62.6 & 31.3 \\
\hline \multicolumn{3}{|l|}{ Annual income (N) } \\
\hline No income & 31.4 & 15.7 \\
\hline $100,000-150,000$ & 152.6 & 76.3 \\
\hline $151,000-200,000$ & 10.0 & 5.0 \\
\hline$>200,000$ & 6.0 & 3.0 \\
\hline
\end{tabular}

Ameh and Iheanacho (2017) associated male dominance in rice farming (which has similar drudgery as yam farming) to laborious nature of 
farming operations right from tillage to harvesting, which their female counterparts cannot easily undertake. Sex interaction with gender might also contribute to high ratio of male to female yam farmers in the study area due to some social and cultural norms preventing female from taking active part in farming practices. Social and cultural norms, roles and attributes such as land acquisition and access to credit might have been responsible for the ratio of male to female yam farmers observed in this study. Bergh et al. (2012) also reported that women's restricted access to critical agricultural resources depended largely on marital status; single women had less access to critical inputs like land and credit than married women. The higher ratio of male to female farmers in the study areas also implies that COVID-19 will have serious effect on the productivity and income of the yam farmers in the study areas due to the sex difference in ACE2 and TMPRSS2 regulation.

Closing the gender gap in terms of access to agricultural inputs could lead to increase in work force, productivity, income, and hunger alleviation, reduction in unemployment and reduction in the negative impacts of COVID-19. Promoting gender equality and women's empowerment is inextricably linked to strengthening food systems, fighting hunger and malnutrition, and improving the livelihoods of rural population (FAO, 2017). More encouragement of females in yam farming will increase availability of family labour for yam production, consequently reducing the amount spent on hired labour. Oboh and Ekpebu (2011) reported that wives and children can serve as cheap source of labour which may lead to increase in their farm size and increase their overall level of farm output.

The age distribution of small-scale yam farmers shows that the majority $(49.5 \%)$ were within the age range of 55-64 years. This is a clear indication that the small-scale yam farmers in the study area were above middle-aged that could not be very energetic to undertake tedious operations in yam farming.

The relatively high number of older yam farmers reported in this study might be attributed to cultural norms, which left land ownership at the level of inheritance system, which does not encourage youths to have access to farmland. Youths likely must have migrated out of the village for greener fields. The manual labour is becoming less attractive for rural youth who also tend to migrate to cities. The trend has changed since 2016 or so due to job losses that characterized the economic policy of this administration. This has been heightened with the emergence of COVID-19. COVID-19 pandemic will adversely affect the productivity and income of the small-scale yam farmers in the study areas because older age groups are more vulnerable to COVID-19 infection than the youth and the middle age. Yam farmers within the age range reported in this study might be at higher risk of having one underlying condition, placing them at increased risk of severe impact from COVID-19. This inference is supported by the United Nations (2020) findings that although all age groups are at risk of contracting COVID-19, older persons are at a higher risk of mortality and severe disease following infection.

Involving youths in small-scale family farming can play a fundamental role in enhancing rural livelihoods, spurring entrepreneurial activity, job creation, on-farm and providing economic opportunities. FAO (2017) reported that integration of young farmers and intergenerational transfer of holdings, youth and women's employment, conditions for exiting small-scale family farming for rural job creation are keys to regional development and poverty alleviation, and to preventing mass migration. Involving younger yam farmers in the farming sector will reduce the number of older farmers who are more vulnerable to infectious disease like COVID-19.

The result shows that majority $(69.2 \%)$ of the respondents were married. The relatively high number of married farmers observed in this study might suggest that couples worked together in their farms to reduce labour cost and improve income. Fu et al. (2011) reported that of farmers had wives who worked on their yam farms. Interestingly, the number of married farmers $(69.2 \%)$ is close to the number of famers $(50 \%)$ above middle age 55-64 years of age which could be more affected by COVID-19 infection. Encouraging youths who are likely to be less susceptible to infection to go into yam farming will go a long way to boost yam productivity and income beyond COVID- 19 .

The result revealed that $52.54 \%$ of the respondents were holders of First School Leaving certificate (FSLC). The findings show that most small-scale yam farmers $(90 \%)$ received formal education. This finding also reveals that most $(62.60 \%)$ of the respondents were not literate enough for effective communication and adoption of agricultural technologies in doing their farming business in the study area except those technologies rendered in user friendly ways. Increased level of education would determine the quality of skills of farmers, their allocative abilities, efficiency and how well informed they are of the innovations and technologies around them (Moyib et al., 2013; Girei et al., 2014). Education has always been known to play a positive role in the adoption of improved technologies among farmers (Mbanaso et al., 2011). Low level of education observed with the smallscale yam farmers in this study could be aggravated by global lockdown due to COVID-19 effect on movement to farm or sought labour. Amorighoye (2020) reported that a struggle was going on prior to COVID-19 to ensure young children stay in school and have access to proper education, as Nigeria contributes approximately $20 \%$ of the total global out-of-school population COVID-19 pandemic is 
revolutionizing digital and online communication education globally. Consequently, rural farmers who are poorly educated are likely to be left behind as they are not equipped to adapt to the new methods of communication/learning. Inability to adopt emerging new methods of communication will cause reduction in acquisition of new skills and innovation that would enhance productivity and income of the farmers. In order to ameliorate this low level of formal education, government agencies should increase access to education for rural people such as adult educational programs. Educational leaders should ensure that what people learn is relevant to feeding the growing population for advancement towards sustainable development including farming and farmers.

Most of the respondents (78.8\%) had farm size of 4.0 hectares. This may be considered sizeable for rural farmer. However, societal laws and norms of land inheritance and communal land ownership often complicate the transfer of land to young women and youth and prohibit the sale of land to farmers who need to expand their farm size. The land ownership by inheritance end up leaving farmland into fragments that do not support farm development. The landshortage is a major factor limiting the increases in smallholder output. This is reflected in low agricultural productivity and annual income of the yam farmers in the study areas. This might be the reason $15.7 \%$ of the yam farmers in the study area could only engage in family farming for family consumption recognizing it as income. The small farm size also reflected in the few number of respondents within the youthful and middle-aged group engaged in farming because most of the yam farmers were not energetic and innovative enough resulting in low productivity. Due to the effect of COVID-19 majority of people are facing job losses especially, in this case, farm labourers who could not be mobilized to farm from different places of their abode or assembly due to restriction on movement. Adesoji (2020) reported that Nigerians are losing their jobs as both individuals and firms due to snowballing effects of the COVID- 19 .

In order to reduce this rate of unemployment government policy should look into land use act and make a decree that will make land acquisition possible for the interested yam farmers in the rural areas. Farm mechanization, use of improved yam varieties and access to loan should be implemented in order to attract the youth and middle-aged group to yam farming and reduce urban migration.

The result shows that the majority of the respondents (65.7\%) had between 31-40 years of yam farming experience while none had yam farming experience of less than 10 years. This implies that most of the respondents are well experienced in yam farming. Ameh and Iheanacho (2017) reported that increase in the years of farming experience leads to farmer ability to manage, operate a farm and increase in the output. These long years of farming experiences support the findings that older people were engaged in small-scale yam farming in the study areas. This implies that due to their age and experience, some of them may not be ready to adapt innovations and new technologies used in yam farming. The educational leaders, agricultural scientists and agricultural extension experts should reshape educational systems, researches and extension activities so as to attract/involve graduates with innovative skills in agriculture/farming.

The result of the annual income of the smallscale yam farmers indicates that the majority (76.3\%) earned between $\$ 100,000$ and $\$ 150,000$ while $15.7 \%$ claimed no income. The annual low income level of small-scale yam farmers in the study area might be due to the increasing number of men being involved in multiple jobs and spending less time on the yam farming. This low annual income from yam farming could be attributed to less number of youths engaged in yam production as full-time farmers; as it is earlier reported that majority $(49.5 \%)$ of respondents were within the age range of 55 and 64 and these cannot be regarded as youths. This is supported by the report of Ikandi and Ayegba (2013) that young farmers are innovative and active at work and therefore when fully engaged in farming could earn high income from yam farming productive stage. The low annual income of the yam farmers is worsened by the effect of COVID containment measures (stay at home, curfew, etc.), which inhibited sourcing of labour and movement to farms from different places of abode. The rural yam farmers were in the informal economy, where staying at home means not being paid. They do not have a salary or social security benefits and some may not have savings (Kinyanjui, 2020). This low income can lead to increase in extreme poverty resulting from economic slowdown, which will translate into its own health burden including death toll.

Investing in youth through farming is the best way to guarantee sustained national growth (FAO, 2018). It will help in creating the right environment for skill development, capacities and innovative building for entrepreneurial potential of country's leader and producers of the future. The level of yam farmer's education reported in this work might be a contributory factor to the low income level observed among the respondents. Increased level of education determines the quality of skills of farmers, their allocative abilities that can lead to increase in income of the farmers. Nkang et al. (2009) reported that education affects the way farms are managed as well as overall production. The least number $(0.5 \%)$ of farmers manage 7-7.5 hectares of farmland, which reflected in lower income of the respondents. This shows that most of the small-scale yam farmers engaged in yam production at subsistence level rather than commercial level. Inheritance laws and customs often complicate the transfer of land to 
Table 2: Correlation coefficient showing relationship between socioeconomic factors and farm characteristics

\begin{tabular}{|c|c|c|c|c|c|c|c|c|}
\hline & Sex & Age & $\begin{array}{c}\text { Educational } \\
\text { level }\end{array}$ & $\begin{array}{c}\text { Primary } \\
\text { occupation }\end{array}$ & $\begin{array}{c}\text { Income per } \\
\text { annum }\end{array}$ & Farm area & $\begin{array}{c}\text { Farm } \\
\text { experience }\end{array}$ & $\begin{array}{c}\text { Marital } \\
\text { status }\end{array}$ \\
\hline Sex & 1 & & & & & & & \\
\hline Age & $-.169^{*}$ & 1 & & & & & & \\
\hline Educational level & -.099 & -.100 & 1 & & & & & \\
\hline Primary occupation & -.018 & -.078 & -.075 & 1 & & & & \\
\hline Income per annum & -.024 & $.151^{*}$ & -.089 & -.077 & 1 & & & \\
\hline Farm area & .070 & $.167^{*}$ & .068 & $-.240 * *$ & .096 & 1 & & \\
\hline Farm experience & $-.193 * *$ & $.541 * *$ & -.106 & -.040 & $.347 * *$ & $.302 * *$ & 1 & \\
\hline Marital status & $.249 * *$ & $.584 * *$ & .090 & -.018 & $-.288 * *$ & $-.255^{* *}$ & $-.932 * *$ & 1 \\
\hline
\end{tabular}

*Correlation is significant at the 0.05 level (2-tailed); ${ }^{* *}$ Correlation is significant at the 0.01 level (2-tailed)

young women and youth. With a review of land inheritance, young people can be assisted by loans to acquire land, and by leasing arrangements through which the youth gain access but not ownership to land (FAO, 2018).

\section{Relationship between Socio-economic Factors and Farm Characteristics of the Respondents}

Table 2 shows that farm experience of the respondents significantly $(p<0.05)$ and positively correlated with age of the respondents $(r=0.541)$. This means that farmers that were older in age had more farming experience. This may support the findings in this study that the majority $(49.5 \%)$ of yam farmers were within the age range of 55-64 years, and these rather old farmers formed the highest proportion of respondents $(65.7 \%)$.

This means that the age of the respondents with higher experience were also within the age ranges that are more vulnerable to COVID-19 infection. This is in support to the United Nations (2020) findings that although all age groups are at risk of contracting COVID-19, older persons are at a significantly higher risk of mortality and severe disease following infection with the virus.

Marital status had positive significant $(p<0.05)$ correlation with age $(r=0.584)$, but negative correlation with farm experience $(r=-0.932)$. This means that the higher the number of married yam farmers the higher their age. The relationship observed between marital status and farm experience implies that the married yam farmers have less farm experience. This might be due to less number of youths recorded in this study (Table 1) involved in yam farming hence proves that the youth participation in yam farming is low.

\section{CONCLUSION AND RECOMMENDATION}

Evidence from this study has shown that socioeconomic factors of small-scale yam farmers from the study areas had adverse effect on the farm characteristics. In order to mitigate the risks of the pandemic now and in the future on food security, the educational leaders, agricultural scientists and agricultural extension experts should reshape educational systems, researches and extension activities so as to attract/involve graduates with innovative skills in agriculture/farming to increase yam productivity and income beyond COVID-19 and accelerate towards inclusive sustainable development.

\section{ACKNOWLEDGEMENTS}

The authors wish to express our gratitude to the Bill and Melinda Gates Foundation for funding the research work.

\section{REFERENCES}

Adesoji B.S. (2020). COVID-19: Survey confirms job losses, hardship for Nigerians. Business News, Available at www.nairametrics.com

Ajibola B. (2020). COVID-19 pandemic-post-effect on rural dwellers and crop production in Nigeria. Retrieved 05 May 2020 https://doi.org/10.13140/ EG.2.2.21984.84488

Ameh M. and Iheanacho A.C. (2017). Socio-economic factors influencing agricultural acquisition among small scale rice farmers in Benue State, Nigeria. Int. J. Innov. Agric. Biol. Res., 5 (4), 8-17

Amorighoye T.A. (2020). COVID-19 has exposed the education divide in Nigeria. World Economic Forum COVID Action Platform. Available at https://www.wforum.org/agenda/2020/06/education -nigeria-covid-19-digital-divide/

Bergh K., Orozco P., Gugerty C. and Anderson L. (2012). Yam value chain: Nigeria. Evans School Policy Analysis and Research, Brief No. 207. p. 28

Cai H. (2020). Sex differences and smoking predisposition in patients with COVID-19. Lancet Respiratory Medicine. https://doi.org/10.1093/cid/ ciaa270

Chappell M.C., Marshall A.C., Alzayadneh E.M., Shaltout H.A. and Diz D.I. (2014). Update on the angiotensin converting enzyme 2-angiotensin (1-7)Mas receptor axis: Fetal programming, sex differences, and intracellular pathways. Front. Endocrinol., 4, 1-13

Dagbelou V.K., Adekambi S.A. and Yabi J.A. (2021). Growth of small and medium sized agricultural enterprises and export market integration by smallholder farmers. Agro-Science, 20 (3), 1-8

FAO (2017). Leaving no one behind: Achieving gender equality for food security, nutrition and sustainable agriculture. Food and Agriculture Organization (FAO) of the United Nations - FAO Conference, $40^{\text {th }}$ Session, Rome, pp. 3-8 
FAO (2018). Food and agriculture to achieve the SDGs: 20 interconnected actions to guide decision-makers. Food and Agriculture Organization (FAO) of the United Nations, Rome

Fu R.H.Y., Kikuno H. and Maruyama M. (2011). Research on yam production, marketing and consumption of Nupe farmers of Niger State, Central Nigeria. Afr. J. Agric. Res., 6 (23), 5301-5313. https://doi.org/10.5897/AJAR11.586

Girei A.A., Dire B., Yuguda R.M. and Salihu M. (2014). Analysis of productivity and technical efficiency of cassava production in Ardokola and Gassol local government areas of Taraba State Nigeria. J. Agric. Forestry Fisheries, 3 (1), 1-5

Hoffmann M., Kleine-Weber H., Schroeder S., Kruger N., Herrler T. and Erichsen S. (2020). Sars-Cov-2 cell entry depends on ACE2 and TMPRSS2 and is blocked by a clinically proven protease inhibitor cell. J. Cell Biol., 181, 271-289

IITA (2020). COVID-19: Work in shifts, researchers advise yam seed producers and farmers. International Institute of Tropical Agriculture (IITA) News, 2020. Available at https://www.iita.org

Ikandi D.A. and Ayegba O. (2013). An impact assessment of agricultural credit on rural farmers in Nigeria. Res. J. Finance Account., 4 (18), 80-89

Kinyanjui M.N. (2020). The Effect of the Coronavirus on the Poor in Africa. Italian Institute for International Political Studies Commentary. Available at https://www.ispionline.it

Klein S.I., Jedlicka A. and Pekosz A. (2010). The Xs and $\mathrm{Y}$ of Immune responses to viral vaccines. Lancet Infectious Diseases, 10 (5), 338-349

Mapila M., Kirsten J. and Meyer F. (2011). Agricultural rural innovation and improved livelihood outcomes in Africa. Centre for the Study of African Economies, Conf. Econ. Dev. Africa, Oxford, UK
Mbanaso E.O., Agwu A.E., Anyanwu A.C. and Onwubuya E.A. (2011). Personal and socioeconomic factors affecting the adoption of sweet potato production technology by famers in SouthEast zone of Nigeria. Agro-Science, 10 (3), 60-68

Moyib F.R., Akinwumi A.J. and Okoruwa V. (2013). Resource-use efficiency of female-cassava farmers in rain-forest zone of Ogun State. J. Agric. Biodiver. Res., 2 (2), 17-23

Mubamba C, Ramsay G., Abolnik C., Dautu G. and Gummow B. (2018). Analysing production and financial data from farmers can serve as a tool for identifying opportunities for enhancing extension delivery among the rural poultry sub-sector in Zambia. Prevent. Vet. Med., 158 (1), 152-159

Muzekenyi M., Zuwrimwe J. and Beata K. (2019). Review of South Africa's small-scale farming entrepreneurial constraints and opportunities: A rural perspective. J. Agric. Allied Sci., 8 (1), 79-85

Nkang N.M., Ajah E.A., Abang S.O. and Edet E.O. (2009) Investment in cocoa production in Nigeria: A cost and return analysis of three cocoa production management systems in the Cross River State cocoa belt. Afr. J. Food Agric. Nutr. Dev., 9, 713-727

Oboh V.U. and Ekpebu I.D. (2011). Determinants of formal agricultural credit allocation to the farm sector by arable crop farmers in Benue State, Nigeria. Afr. J. Agric. Res., 6 (1), 181-185

Patel S.K., Velkoska E. and Burrell L.M. (2013). Emerging markers in cardiovascular disease: Where does angiotensin-converting enzyme 2 fit in? Clin. Exp. Pharmacol. Physiol., 40 (8), 551-559

SAS (2012). SAS user's guide. Statistical Analysis System, Version 9.4, Institute Inc Cary

United Nations. (2020). Policy brief: the impact of COVID-19 on older persons. http://www.un.org/develop ment/desa/ageing/wp-content/uploads/sites/24/2020/05/C 